\title{
The EU/China relationship: not seeing eye to eye?
}

\author{
Ali M. El-Agraa
}

Published online: 23 May 2007

(C) Springer-Verlag 2007

\begin{abstract}
I consider the endeavours exerted by the EU to develop the relationship with China which it formalised in its 1995 document 'A Long Term Policy for China-Europe Relations' (COM(1995) 279 final). I then examine China's responses which culminated in 2003 when China produced its first ever 'China's EU Policy Paper.' The reasons for this long gap between initiation and response are then explored. Since, obviously, the EU has been driving the relationship, the rationale for this is then looked into and detailed data is provided to support it. Finally, the nature of China's reciprocation is entertained before the paper concludes that the relationship appears to mean more to the EU because China perceives the EU as only having a limited role within China's overall global aspirations, of becoming a world power in economic terms, resulting from its impressive rate of economic growth, increasing R\&D expenditure, and continually enhancing sophistication of its technology, and politically with its developing links and military prowess.
\end{abstract}

\section{Introduction}

China is in the limelight and rightly so. By this, the reference is not to the country's recent international leadership activities, including enticing the Democratic People's Republic of Korea (DPRK) back into the six-nation talks; ${ }^{1}$ holding/hosting the Summit of the Forum on China-Africa Cooperation (FOCAC) in November 2006

${ }^{1}$ The six nations are China, Japan, the two Koreas, Russia and the US.

A. M. El-Agraa $(\bowtie)$

Faculty of Commerce, Fukuoka University, Nanakuma, Jonan-ku, Fukuoka 814-0180, Japan e-mail: elagraa@fukuoka-u.ac.jp

URL: http://www.fukuoka-u.ac.jp/ali/index.html 
with 48 of the 50 African nations, a feat never achieved by the Africans in their own fora; and the eight-nation 12-day tour of Africa by Chinese President Hu Jintao in January/February 2007. ${ }^{2}$ One could even admire these initiatives, because despite the self-interest, i.e. securing China against an influx of escapees from DPRK if that country were completely isolated from the international community, not to mention securing a nuclear-free Korean peninsular, and attracting much needed energy and mineral resources from Africa, these are moves which are bound to impact positively not only on the Asian but also global security.

China is in the limelight because it has been one of the fastest growing economies in the world, averaging about 10\% Gross National Income (GNI) growth over the past decade or so. Indeed, by 2004 the Chinese economy surpassed that of France to become the world's fifth largest, after the US, Japan, Germany and the UK. This trend is confirmed by the latest figures, released in the press in early 2006, which place China ahead of the UK; not surprising given that in 2003 the UK's GNI amounted to \$2.01 trillion while China's was \$1.94 trillion, a difference of a mere $3.5 \%$. What is even more striking is that China is now an increasingly substantial player in global trade. In 1980, its total trade was $\$ 38$ billion, accounting for $1 \%$ of total global trade. By 2003, however, this has increased to $\$ 851$ billion, raising the share to $5.6 \%$ to elevate China to the rank of fourth largest world trader, following the US, Germany and Japan. Indeed, this trend seems to have been maintained since the latest data ${ }^{3}$ shows that in 2005 China replaced Japan as the third largest world trader with $\$ 1.42$ trillion of trade, of which $\$ 762$ billion were exports (up 28\% from 2004 ) and $\$ 660$ billion were imports (up 18\%). Furthermore, and much to the surprise of many countries headed by Japan, 2006 OECD projections reveal that China would be second to the US in the league of R\&D expenditure, measured in

\footnotetext{
2 The tour is his third during the past 2 years, with the second taking place during April 2006. The latest tour began on 30 January 2007 and included stops in Liberia, Sudan, Zambia, Namibia, South Africa, Mozambique and Seychelles. It marked his first visit to Africa after holding/hosting the FOCAC in November 2006, when he pledged \$5 billion in loans and credits to Africa during 2006-2009 and declared the formation of a $\$ 5$ billion China-Africa 'development fund' aimed at encouraging Chinese enterprises to invest in African countries as well as provide them with support; for details, see Worldpress.org (2007) http://www.worldpress.org/print_article.cfm?article_id=2674\&dont=yes 'China to double aid to Africa.' The Chinese have claimed that the visit was remarkably successful in enhancing friendship and cooperation between China and African nations (see China View, 'Chinese President Hu Jintao wraps up successful African trip,' published in 2007 and can be accessed from their website at: http://news. xinhuanet.com/english/2007-02/11/content_5724926.htm) and the Africans are pleased with the mentioned cheaper credit it has promised to extend to them. Note that: in the first 10 months of 2005, Chinese companies invested $\$ 175$ million in African countries, mainly on oil exploration projects and infrastructure; at the end of October 2005, China's trade with Africa amounted to \$32.17 billion, making it Africa's third most-important trading partner, behind the US and France and ahead of the UK; and China's foreign direct investment (FDI) in Africa reached $\$ 900$ million in 2005 out of a total of $\$ 15$ billion (i.e. 6\%). Detailed information can be found in Pan (2007) 'China, Africa and oil' under the Council on Foreign Relations, to be accessed at: http://www.cfr.org/publication/9557.

${ }^{3}$ Released on 11 January 2006 and published in all the major news media, including the Financial Times, on 12 January 2006.
} 
terms of 'Purchasing Power Parity' (PPP), for the first time relegating Japan to third place. 4

Over the same period, the pattern and composition of China's trade have also experienced dramatic changes. Instead of having its exports continuing to be concentrated on primary products, a characteristic of very poor nations, they have become dominated by industrial products, especially those of the capital-intensive type, which is a feature of advanced nations. Such a speedy transformation under China's circumstances is most unexpected, i.e. could not be predicted by any trade model, given that China is still a very poor nation, ranking 108 in 2004 in terms of per capita PPP GNI, with $\$ 5,890 .^{5}$ This raises several questions. What has been happening to the Chinese economy that enabled such a transformation? Have the policies being adopted by China been the main instigators of this? What is the precise nature of the export commodity composition brought about by this change? How has the change in the composition of exports impacted on China's direction of trade? What has been the consequence of this transformation on the nature and composition of China's imports?

These questions are however not the subject of this paper, not only because they have been addressed elsewhere, ${ }^{6}$ but also because my concern here is with the extent to which the European Union (EU) has been preparing itself to deal with China's transformation and how to capitalize on China's huge economic potential for trade and investment. Hence, the paper commences by describing the efforts exerted by the EU in this respect which it formalised in 1995 in its EU-China relationship policy document. The paper then proceeds to consider China's responses which culminated in 2003 when China produced its own first ever China-EU policy paper. The reasons for this long gap between action and reaction are then explored. It is obvious from this that the EU has been driving this relationship so the rationale for this is then explored. Finally, the nature of China's reciprocation is examined before the paper is concluded. The main finding is that the relationship means more to the EU because China perceives it within its global aspirations, based on its potential economic power.

\section{Initiating the relationship}

In its Communication (COM) of 1995 concerning a strategy for the establishment of a long-term policy for relations between the EU and China, ${ }^{7}$ the European

\footnotetext{
${ }^{4}$ According to the OECD's Science, Technology and Industry Outlook, published in 2007, China's R \& D expenditure in 2006, as measured in PPP terms, is expected to be \$136 billion while that by the US, Japan and EU-15 would be \$330, \$130 and \$230 billion, respectively. The OECD arrives at the figures for 2005 and 2006 by projecting on the assumption of a continuation of growth in R \& D spending in these years 'at the same average rate as was observed over the period 2000-2004'; a fairly standard projection practice. Japan's shock is due to its obsession with nominal exchange rate valuation which reduces China's R \& D to only $\$ 33$ billion or $1.3 \%$ of its GDP; under the same terms, Japan's would be $3.17 \%$ of its GDP; see OECD (2007), which can be accessed at: http:/www.oecd.org/sti/outlook. However, no economist would or should settle for comparative data that is not based on PPP valuation.

${ }^{5}$ At nominal exchange rates, it ranks 129 and its per capita GNI is only $\$ 1,500$.

${ }^{6}$ El-Agraa and Wei $(2006 \mathrm{a}, \mathrm{b})$.

${ }^{7}$ Commission of the European Communities (1995). This was the culmination of efforts on the part of the EC to promote bilateral political dialogue with China that started in June 1994.
} 
Commission expressed its realisation of the uniqueness of China's ascendance since the end of the Second World War. Unique because while Japan acquired economic prowess and Russia continued to survive on the basis of military strength, China was 'increasingly strong in both the military-political and the economic spheres.' On the economic front, the Commission relied on, inter alia, IMF and World Bank extrapolations, based on then prevailing PPP GDP and its growth rates, to forecast that China would become the world's largest economy in a generation's time. The EU obviously had an interest in developing its economic relations with a future superpower but its interest went beyond the economic. With population increasing, despite the one-child policy, by 15 million annually and China is already second only to the US in terms of energy consumption, it would impact greatly on energy demand; hence on the physical environment. The Commission concluded that the consequences for the environment of a huge China reaching western consumption, and pollution, levels in the future would be impossible to ignore. It was therefore vital that China should play a full part in the wider policy exchange on such key issues as the environment, population and health. Moreover, with China still poor, ${ }^{8}$ a substantial number of Chinese would seek emigration, which would increasingly become subject to illegal trafficking due to limited licit access to EC and other nations. It was therefore essential to tackle the 'very real resultant problems' in close cooperation with China.

As to the military-political, the Commission emphasised that China's size (in terms of both area and population, then 1.2 billion), nuclear power status and permanent membership of the UNSC clearly indicated that it would become impossible to tackle international issues without factoring in China's impact on their development and management, especially since the country was 'one of the world's biggest arms producers and exporters.' Hence China's 'role across the whole security spectrum is central to global, as well as regional security.'

The Commission pointed out that while China was domestically undergoing sustained and dramatic economic and social change, it was simultaneously increasing its involvement in the world security and economic systems. On the domestic side, China's hugeness was reflected 'in the multiplicity of players...who can influence Chinese policy and practice': central government agencies, both in Beijing and elsewhere, provincial and municipal authorities; emerging economic actors; and the like. This, together with the rapid devolution in economic power was delegating policy responsibility and implementation for economic and trade matters to the provincial level. The Commission concluded that it would thus be vital to have firm commitments on the enforcement of China's international obligations at the sub-national level, for example, during the World Trade Organization (WTO) negotiations. It reiterated that this 'makes it crucial to expand our bilateral trade and cooperation discussions to include provincial and local authorities which, de jure or de facto, are in charge of economic and trade policy in many fields.'

\footnotetext{
${ }^{8}$ In 1995 , China had a per capita GNP of $\$ 2,920$ in PPP terms ( $\$ 620$ in nominal exchange rate terms), ranking 42 from the bottom in the World Bank's (1977) list of 'low-income economies,' published in its World Development Report. 
All this was happening at a time of 'globalization'9 with problems such as the protection of the environment and nuclear non-proliferation requiring coordinated action by all countries. We were reminded that in its endeavours to become part of this global dynamic, China joined the IMF and the World Bank in the early 1980s; became a member of the APEC forum ${ }^{10}$ (in 1991); was actively negotiating membership of the WTO; contributed significantly to the outcome of the World Conference on Human Rights in Vienna in June 1993; and would be hosting a major UN conference on women later in 1995.

The Commission pointed out that two decades had passed since the EC and China engaged in diplomatic relations in $1975^{11}$ and a decade since the signing of the Trade and Cooperation Agreement ${ }^{12}$ between them in 1985; the agreement was: both broader in scope relative to that of 1975 , providing a framework for cooperation in industry, mining, energy, transport, communications and technology; and more flexible with regard to trade and economic cooperation. ${ }^{13}$ Although bilateral relations were severed in $1989^{14}$

\footnotetext{
${ }^{9} \mathrm{~A}$ fashionable and over-played term since those specialised in International Economics have always referred to 'international interdependence' and its increasing occurrence. See, inter-alia, Bhagwati (2002), Fischer (2003), and Ali El-Agraa (2004b).

${ }^{10}$ Not that such membership has any significance when the mere mention of possible discussions on the creation of a free trade area for the 21 member nations of APEC is met by complete silence by all as happened during their meetings in November 2006, held in Hanoi, Viet Nam. See, inter alia, El-Agraa (1999); and (ed.) The European Union: Economics and Policies, Cambridge University Press, forthcoming in early 2007-the seventh edition was published in 2004 by Pearson Education, Prentice Hall and Financial Times, Hemel Hempstead, UK.

${ }^{11}$ Diplomatic relations were established in May 1975, following the visit to China by Commissioner Sir Christopher Soames. The resumption of diplomatic relations was supposed to quickly pave the way for trade and economic relations, but the chaos that beset China in the aftermath of the passing away of Mao Zei Dong in 1976 put on hold all contacts between the Commission and China (Kapur 1981, p. 201). However, in 1980 China was admitted into the group of developing nations granted special treatment under the EC's Generalised System of Preferences (GSP). Griese (2006) claims that EC-China trade relations after that progressed so rapidly and positively that the 1978 agreement had to be considered inadequate for its purposes and hence a new agreement was in order.

${ }_{12}$ Agreement on Trade and Economic Cooperation between the European Economic Community and the People's Republic of China-1985, which can be accessed at: http://ec.europa.eu/comm/external_ relations/china/intro/1985_trade_agreement.htm (Commission of the European Communities 1985).

${ }^{13}$ Examples of this cooperation are the Science and Technology Agreement of 1999, which was renewed in 2004, and the Maritime Agreement of 2002, which aimed 'to improve conditions for the maritime transport of EU and Chinese companies moving from the EU, China and third-party destinations' (see Griese 2006, p. 546).

${ }^{14}$ After EC Commissioner Sir Christopher Soames' visit to China in 1975, there followed in 1979 the first ever visit by a president of the European Parliament (EP), Mr Emilio Colombo, and a month later the first such visit by a president of the Commission, Mr Roy Jenkins, who met personally with the Chinese leader Deng Xiaoping. These visits would seem (as claimed by Griese 2006) to have paved the way for a meeting in Strasbourg in June 1980 between delegations from the EP and the Chinese National People's Congress, but there is no concrete evidence to support this conjecture. They also led to: the launching in 1983 of the first EC-China Scientific Cooperation Programme; and the setting up in 1988 of the EC Delegation offices in Beijing. However, no high-ranking official visit to the EC by a Chinese took place until Prime Minister Zhu Rongji visited the Commission in Brussels in June 2000.
} 
in the aftermath of the Tiananmen Square brutal crack down on Chinese dissidents ${ }^{15}$, their normalisation, especially during the early 1990s, had led to enhanced trade and investment ${ }^{16}$ and culminated in the 1994 arrangement for 'political dialogue.'

With that background in mind, the Commission thus urged that it was high time to 'redefine' the EU relationship with China, within the context of the new Asia Strategy endorsed by the Essen European Council. ${ }^{17}$ It emphasised that the EC 'must develop a long-term relationship with China that reflects China's worldwide, as well as regional, economic and political influence.' That was because 'relations with China are bound to be a cornerstone in Europe's external relations, both with Asia and globally.' It added that the EC 'needs an action-oriented, not a merely declaratory policy, to strengthen that relationship.'

The rest of the Communication examined the specific concerns of the EC, especially how to enable EC enterprises compete successfully in the expanding Chinese market, and developed a detailed picture of all these considerations as well as articulated policy recommendations and actions on each. These details will become apparent in the following section when I turn to China's response, but here it can be briefly stated that the conclusions drawn by the Council on the basis of the Communication set the aims of the EC-China relationship to be:

1. To engage China further, through upgraded political dialogue, in the international community;

2. To support China's transition to an open society based upon the rule of law and the respect of human rights;

3. To integrate China further in the world economy by bringing it more fully into the world trading system and by supporting the process of economic and social reform underway in the country, including in the context of sustainable development;

4. To make better use of existing EC resources; and

5. To raising the EC's profile in China.

All the essential elements in the Communication were formally adopted by the Commission on 25 March 1998 in its 'Building a comprehensive relationship with China' ${ }^{18}$ and endorsed by the Council on 29 June 1998 (see European Council 1999). Hence this 1998 document establishes the reference point for the EC's policy for the relationship.

\footnotetext{
${ }^{15}$ Two days after 4 June 1989, the EC condemned the 'incident' and during the 26-27 June 1989 Madrid European Council meetings, the EC imposed several sanctions on China, eliminating high-level EC-China meetings and leading to the suspension of new cooperation projects and the curtailment of programmes then in action. However, in 1990 the EC relaxed its embargos on contacts and cooperation, when it was realized that no change in Chinese leadership was going to ensue from the incident; the only exceptions being the ban on arms sales and cooperation in the military field (see Griese 2006, p. 547).

${ }^{16}$ Indeed, Algieri (2002, p. 64) argues that the Tiananmen incident caused no ' major disturbance [in] EUChina economic relations.'

${ }^{17}$ This relates to the endorsement by the Council, held on 9/10 December 1994, of the Commission's 'Towards a New Asia strategy' (COM(94) 314). The Council concluded that it 'emphasizes the economic and political significance of the countries of the Asia-Pacific region and reaffirms that the European Union and its Member States wish to strengthen cooperation and dialogue at all levels with the countries and regional organizations in the Asia-Pacific region, in particular ASEAN.' It urged the Council (of Ministers) and Commission to report to it as soon as possible on the practical measures taken in that respect. See Bulletin of the European Union, 1994, No. 12, p. 14.

${ }^{18}$ Commission of the European Communities (1998). 


\section{China's reciprocation}

For a long time, no equivalent response was forthcoming from China. That however would/should not have surprised the EC since its policy paper was not only an act of 'unilateral declaration' and hence the EC had to follow it by endeavouring to sell it to China by negotiating its various aspects, item by item, especially if China did not see the need for a policy. But also, and vitally, the EC policy sent a double-edged message: wanting to benefit from the vast economic potential of China yet simultaneously dictating conditions which countered China's socio-political stance. Beggars cannot be choosers, although much needed sanctioning of China's bid for WTO membership provided a counterweight - see below. Indeed, the very fact that the EC deemed it necessary to publish a Report on progress with the policy on 8 September $2000^{19}$ under the circumstances is a clear manifestation of an EC having been engaged in a 'selling exercise.' The Report stated that since the adoption of the 1998 Communication, the EU-China relationship had greatly intensified, with the annual EU-China summits in 1998 and 1999 laying the foundations for a broader political dialogue. Also, simultaneously, an increasing succession of meetings and dialogues at all levels, and in numerous areas of concern to both sides, 'improved communication and promoted mutual understanding.' Moreover, the agenda were extended to regional security, economic/trade concerns as well as to human rights and the EC expressed its wish for the inclusion of other global issues such as illegal immigration and 'eventually drugtrafficking, money laundering and organised crime.' Furthermore, the two signed a Bilateral Agreement on 19 May 2000, needed for China's accession to the WTO, and in this regard, it was stressed that once a member, 'a key challenge for the EU will be to develop mutually acceptable methods to monitor and assist with China's compliance with its WTO commitments.' The EU would also carry on pressing China to tackle remaining barriers to its markets. Finally, the EU-China Cooperation Programme had expanded steadily, focusing on 'sustainable development to assist China's overall reform process' and its priorities and contents would be re-examined in the light of 'the pace of constant change, as well as to improve the impact and visibility of EU assistance to China.' Nevertheless, none of the mentioned items suggests that China saw its role in them as anything but one of being engaged in a 'buying exercise': participation in the China-EU summits should be seen in the wider context of the Asia-Europe meetings (ASEM) ${ }^{20}$ instigated by Singapore; including new items to the agenda was an EU, not a mutual, wish; and so on and so forth.

It could of course be argued that pursuing the relationship, especially on facilitating WTO membership in 2001, must have impacted the EU favourably on China. ${ }^{21}$ This is because on 13 October 2003, China published its formal document

\footnotetext{
${ }^{19}$ Commission of the European Communities (2000).

${ }^{20}$ The first ASEM meeting was held on 2-3 March 1996 in Bangkok and the second in April 1998 in London. For a detailed discussion, see El-Agraa (2001).

${ }^{21}$ Indeed, the EU was a positive, almost vehement, advocate of China's bid for WTO membership and acted as a vital mediator between the US and China in their negotiations on the membership status for China: the US was adamant that China should be treated as an 'industrialised nation' while China was all for being deemed a 'developing nation' with all the privileges such a status would entail, e.g. GSP treatment; see footnote 8. This point is fully set out in Eglin (1997).
} 
on the subject: China's EU Policy Paper. ${ }^{22}$ Since about 2 years had lapsed by then, obviously the Paper did not immediately follow the Report, but that could be due to the factors just mentioned and/or the time-consuming Chinese political decisionmaking process. Other reasons could be the need for further consideration of some issues by China and/or that some points needed further clarification from the EC; I shall return to this point later. An alternative scenario for China's response however would be the one mentioned above; that China had to bend somewhat to the EC since without EC endorsement a safe passage to WTO membership would have been out of the question, when that aim was uppermost in China's priorities at the time. Be that as it may, it is pertinent to look into what the Paper had to say.

The Paper commenced in a grandiose, EU-detached, fashion:

The international situation has been undergoing profound changes since the advent of the new century. The trend towards world multipolarity and economic globalisation is developing amid twists and turns. Peace and development remain the themes of the era. The world is hardly a tranquil place and mankind still confronted with many serious challenges. However, preserving world peace, promoting development and strengthening cooperation, which is vital to the well-being of all nations, represents the common aspiration of all peoples and is an irreversible trend of history.

China is committed to turning herself into a well-off society in an all-round way and aspires for a favourable international climate. China will continue to pursue its independent foreign policy of peace and work closely with other countries for the establishment of a new international political and economic order that is fair and equitable, and based on the Five Principles of Peaceful Co-existence. China will, as always, respect diversity in the world and promote democracy in international relations in the interest of world peace and common development (italics added).

It was only after this grand gesture, emphasising China's awareness of its place in the world, what it stood/aspired for and how it saw the entire globe within that context, vitally omitting any hint to the 'promotion of democracy' applying 'domestically,' that it turned to the relationship:

The...EU...is a major force in the world. The Chinese Government appreciates the importance the EU and its members attach to developing relations with China. The present EU Policy Paper of the Chinese Government is the first of its kind and aims to highlight the objectives of China's EU policy, and outline the areas and plans of cooperation and related measures in the next five years so as to enhance China-EU all-round cooperation and promote a long-term and stable development of China-EU relations (italics added).

It is interesting that the Paper should mention the importance the EU and its member states attach to the relationship, without a reciprocation of the sentiment by China; a vindication of the double-edged nature of the EC policy, one edge of which China wants off the agenda. It could of course be argued that that could have been merely a manifestation of the fact that China was acting in reciprocation to being

\footnotetext{
${ }^{22}$ Ministry of Foreign Affairs of the People's Republic of China (2003).

Springer
} 
approached by the EC, or that it was a question of style, may be even of semantics, or that the devil was in the detail, and so on and so forth. I shall return to dispute this alternative later, so keeping it in mind for the time being, let me turn to the details.

The main body of the Paper consisted of three parts. The first comprised three short paragraphs, ten full lines in total, about the EU itself. The last paragraph confidently stated that ' $[\mathrm{d}]$ espite its difficulties and challenges ahead, the European integration process is irreversible and the EU will play an increasingly important role in both regional and international affairs.'

Part two was less brief and set out the general tone of China's EU policy. Its gist was that the establishment of diplomatic relations between China and the EC in 1975 bestowed benefits on both. That, irrespective of 'twists and turns,' the relationship as a whole was 'growing stronger and more mature' and was 'on the track of a comprehensive and sound development,' citing as evidence some of the items mentioned above in the EC Report. What is significant was the statement that the relationship was 'now better than at any time in history.'

After adding that there were no fundamental differences between the two and that neither posed a threat to the other, the tone however changed somewhat dramatically: 'given differences in historical background, cultural heritage, political system and economic development level, it is natural that the two sides have different views or even disagree on some issues' (italics added). And was quick to reiterate that China-EU relations, based on mutual trust and mutual benefit 'cannot and will not be affected if the two sides address their disagreements in a spirit of equality and mutual respect' (italics added).

The tone then became more positive and less self-assertive:

The common ground between China and the EU far outweighs their disagreements. Both...stand for democracy in international relations and an enhanced role for the UN. Both are committed to combating international terrorism and promoting sustainable development through poverty elimination and environmental protection endeavours. China and the EU are highly complementary economically thanks to their respective advantages. The EU has a developed economy, advanced technologies and strong financial resources while China boasts steady economic growth, a huge market and abundant labour force. There is a broad prospect for bilateral trade and economic and technological cooperation. Both China and the EU member states have a long history and splendid culture each and stand for more cultural exchanges and mutual emulation. The political, economic and cultural common understanding and interaction between China and the EU offer a solid foundation for the continued growth of China-EU relations (italics added).

Again, there was no mention of democracy being extended to 'domestic relations.' Before the details got set out, it was indicated that the strengthening and enhancement of the relationship was 'an important component of China's foreign policy' and that 'China is committed to a long-term, stable and full partnership with the EU.' The objectives were then stated to be:

1. To 'promote a sound and steady development of China-EU political relations under the principles of mutual respect, mutual trust and seeking common ground while reserving differences, and contribute to world peace and stability.' 
2. To 'deepen China-EU economic cooperation and trade under the principles of mutual benefit, reciprocity and consultation on an equal basis, and promote common development.'

3. To 'expand China-EU cultural and people-to-people exchanges under the principle of mutual emulation, common prosperity and complementarity, and promote cultural harmony and progress between the East and the West.' (Italics added).

Part three came in five major sections, covering the policy for the various facets of the relationship. One section dealt with the political elements, stressing various aspects. There was a call for the strengthening of the exchange of high-level visits and political dialogue. Abiding by the 'one-China principle' was stressed, clearly telling the EU to not engage with Taiwan or help it endeavour for independence. The encouragement of the cooperation of Hong Kong and Macao with the EU was agreed, but within the context of the 'one country, two systems.' The promotion of the understanding of EU 'personages of various circles' of Tibet was mentioned, with the important proviso that the EU should not have any contact with the 'Tibetan government in exile' or 'provide facilities to the separatist activities of the Dalai clique.' The continuation of the dialogue on human rights was acknowledged on the understanding that 'both consensus and disagreements' exist between China and the EU in this regard. The strengthening of international cooperation, including on UN matters, advancing Asia-Europe cooperation by working together as equals to 'make ASEM a role model for inter-continental cooperation' and 'a channel for exchange between the oriental and occidental civilisations and a driving force behind the establishment of a new international political and economic order,' joint combating of terrorism and promoting arms control all find a place. So did the enhancement of mutual understanding between Chinese and EU legislative bodies, including with the European Parliament. A final aspect was the increase of the exchanges between the Chinese Communist Party and EU parties at all levels 'on the basis of independence, complete equality, mutual respect and noninterference in each other's affairs' (italics added).

The second section covered various economic matters. One of these was China's commitment 'to developing dynamic, long-term and stable economic cooperation and trade with the EU' with the expectation that the EU would become China's largest trading and investment partner. Another related to financial cooperation, including between central banks and deepening cooperation in preventing and managing financial crises and combating the financing of terrorism and money laundering.' Agricultural cooperation, including the intensification of exchanges in production, processing technology and sustainable development was mentioned. Environmental cooperation, calling for the creation of a mechanism for dialogue between ministers of the environment got a place. Another was IT cooperation, with China expecting EU 'participation in China's IT promotion.' Energy cooperation, with efforts to be exerted to ensure a successful China-EU Energy Conference was also stated. A final aspect was transport cooperation, including within the framework of the China-EU Agreement on Maritime Transport, cooperation in highway technology and management and the deepening of exchanges in civil aviation.

The third section was reserved for education, science, technology, culture, health and press and personnel exchanges. With regard to cooperation in science and technology, there was mention of the protection of intellectual property rights, the encouragement of 
Chinese institutions to participate in the EU Framework Programme for Research and Technological Development, and China's partaking in the EU Galileo Programme. The enhancement of cooperation in international 'big science' projects; the elevation of the role of the Scientific and Technologic Cooperation Steering Committee; insuring the success of the China-Europe Science \& Technology and Innovation Policy Forum and the like were the remaining aspects.

As to the other mentioned areas, China would seek 'a multi-level and alldimensional' framework for cultural exchanges, establish Chinese cultural centres in both EU capital cities and at the EU headquarters in Brussels and encouraged the EU to do likewise. Educational exchanges would be enhanced at all levels, a China-EU education cooperation mechanism established and cooperation strengthened in such fields as mutual recognition of academic qualifications, student exchanges, language teaching, exchange of scholarships and teacher training. Vitally, efforts would be exerted to ensure a successful China-Europe International Business School in Beijing by employing top professionals. The teaching of each other's languages was to be encouraged and supported. Health area cooperation should be reinforced especially regarding the prevention and control of SARS, HIV/AIDS and serious diseases, and efforts made to create a mechanism for mutual information and providing technical assistance in the advent of public health hazards. Exchanges and cooperation between the press and those concerned with the media would be enhanced. And exchanges at the personal level and between non-governmental organisations would be encouraged such that visa problems would be promptly handled, illegal immigration combated and so on.

The fourth section addressed social, judicial and administrative concerns. It called for strengthened cooperation on the employment of legal immigrants and the protection of their work rights, and for the two to strive for a bilateral social security agreement, implement their joint social security programme and broaden exchanges in social insurance of various types. It asked for the continuation of legal and judicial cooperation, a broadening of related areas and the like and specifically for exploring cooperation in judicial administration in the combating of cross border crime and the possibility for the creation of a mechanism of annual meetings between high-level judicial officials. China would strengthen exchanges with relevant EU police agencies and with Europol, broaden substantial cooperation with EU member state law enforcement agents and increase coordination in case handling and information sharing, and China and the EU should support and actively participate in UN peacekeeping and other activities.

The fifth section related to the military. High-level exchanges between the militaries of China and the EU would be maintained and the two gradually develop and improve a strategic security consultation mechanism, exchange more missions of military experts and expand exchanges concerning the training of military officers and defence studies. The EU was asked to lift its ban on arms sales to China at an early date 'so as to remove barriers to greater bilateral cooperation on defence industries and technologies'; yet another point consistent with China's asking the EC to keep off its socio-political domain.

\section{Comparing the EU/China policies}

One can construct a table listing the details, item by item, with the EU policy on the left column and China's policy responses on the right. That is however not necessary, not only because it should not be a daunting task to recall the details from the description 
given above, but also because space limitations dictate otherwise. However, every item in the China Paper is more or less a direct response to one mentioned in the EU's. Also, and vitally, that the dominant concern in both policy papers is with issues relating to trade and investment, and particularly for China, investment embodying technology transfer. The essential differences are political in nature: China's reiteration of its being an equal, its integrity respected, its domestic 'democratic' practices not questioned and that the EU should keep out of matters Taiwanese/Tibetan and other 'internal' human rights' considerations. To put it differently, China's response clearly indicates that it will not move an inch on matters concerning its socio-political stance, ${ }^{23}$ hence confirming the double-edged nature of the message in the EC policy and its rejection of the second edge.

\section{Following up the relationship}

The Commission followed up its own policy by offering regular assessments on progress. The first was issued on 15 May $2001,{ }^{24}$ the second on 10 September $2003^{25}$ and the latest on 24 October $2006 .^{26}$ The first assessment concluded that the global and long-term aims set in 1998 remained largely valid, but there was scope for making EU policy more effective by 'broadening dialogue and co-operation and fine-tuning existing instruments,' after taking into consideration developments that took place since then. The emphasis was mainly on 'defining concrete and practical short and medium term action points' that led to the final objectives.

Major changes not only in the EU and China, but also worldwide took place before the second assessment in 2003. In the EU, the $€$ became a reality, enlargement to include ten new members from central and Eastern Europe was imminent and responsibility for justice and home affairs (JHA) introduced. ${ }^{27}$ China acceded to the

\footnotetext{
$\overline{{ }^{23} \text { It could be claimed that item } 9}$ of the latest EU-China Summit, held in Helsinki on 9 September 2006, contradicts this assertion, but all that it stated was that the "two sides underlined their commitment to the protection and promotion of human rights and continued to place a high value on the EU-China human rights dialogue. They underlined the importance of concrete steps in the field of human rights and reaffirmed their commitment to further enhance co-operation and exchanges in the field on the basis of equality and mutual respect, while making every effort to achieving more meaningful and positive results on the ground. The EU welcomed China's commitment to ratifying the International Covenant on Civil and Political Rights...as soon as possible. Both sides confirmed their commitment to co-operate with UN human rights mechanisms and their respect for international human rights standards provided for in relevant international human rights instruments including the rights of minorities.' Affirmations do not add up to a changed Chinese stance, especially when they are 'international,' rather than domestic. See press. office@cnsilium.europa.eu and http://www.consilium.europa.eu/Newsroom. It is because all the summit joint statements are in this fashion, no space has been devoted to them in this paper.

${ }^{24}$ Commission of the European Communities (2001).

${ }^{25}$ Commission of the European Communities, 'A maturing partnership-shared interests and challenges in EU-China relations,' Communication from the Commission to the Council and European Parliament COM (2003) 533 final, Brussels.

${ }^{26}$ Commission of the European Communities $(2006 \mathrm{~b}, \mathrm{c})$. The strategy set up in this document was preceded by that in Commission of the European Communities (2006a), and an overview of the relationship can be found in Commission of the European Communities (2006e).

27 Details of these and other EU developments can be found in El-Agraa (2004a).

Springer
} 
WTO in 2001 and had new leadership installed. Globally, terrorism, in the aftermath of 9/11, weapons proliferation, major threats such as SARS (Severe Acute Respiratory Syndrome) and protectionism dominated. Hence, the assessment not only considered the progress to date but also reiterated the goals set in 1998 and endorsed and concretized in 2001 as well as added these new dimensions. The assessment was endorsed by the European Council on 13 October 2003.

The third assessment began by noting China's enhanced world prowess: emergence as a major power over the previous decade; becoming the fourth largest economy and third largest exporter; and, increasing political dominance. It claimed that impressive economic performance steered China towards a 'significantly more active and sophisticated' foreign policy and aspirations for 'a place in the world commensurate with its economic and political power' (italics added). With phenomenal growth and huge size, these changes therefore 'have a profound impact on global politics and trade.' As to its own counterpart, it reiterated that apart from being the largest world market, the EU became the home to a global reserve currency; was playing a pivotal role in seeking sustainable solutions to today's challenges, on the environment, energy and globalization; had shown its ability to exert progressive influence internationally; and became the top provider of development assistance. It called on the EU 'to respond effectively to China's renewed strength,' because dealing with the main issues the EU was facing such as climate change, employment, migration and security, "we need to leverage the potential of a dynamic relationship with China based on our values' as well as taking interest in endorsing the Chinese reform process. It concluded that this implied 'factoring the China dimension into the full range of EU policies' at all levels whether domestic or international and 'close co-ordination inside the EU to ensure an overall and coherent approach.' Given these developments and that the 2003 EUChina agreement on a strategic partnership reflected the significance of the relationship between the two, the overall evaluation was that some differences remained, but were being 'managed effectively, and relations are increasingly mature and realistic.' Also, that together with the EU, China was 'closely bound to the globalization process and becoming more integrated into the international system.'

Yet this was a glossy picture since the assessment immediately went on to state that although the fundamental stance must continue to be one of engagement and partnership, with closer partnership, 'mutual responsibilities increase' (italics added). Since a partnership must address the interests of both participants, the assessment stressed that 'the EU and China need to work together as they assume more active and responsible international roles, supporting and contributing to a strong and effective mutual system,' the aim being that 'China and the EU can bring their respective strength to bear to offer joint solutions to global problems.' In other words, not all was rosy:

Both the EU and China stand to gain from our trade and economic partnership. If we are to recognise its full potential, closing Europe's doors to Chinese competition is not the answer. But to build and maintain political support for openness towards China, the benefits of engagement must be fully realised in Europe. China should open its own markets and ensure conditions of fair competition. Adjusting to the competitive challenge and driving a fair bargain 
with China will be the central challenge of EU trade policy in the decade to come. This key bilateral challenge provides a litmus test for our partnership, and is set in more detail in a trade policy paper... ${ }^{28}$

The bottom line was that the EU and China together can do more to promote their own interests than they will ever achieve apart (italics added).

In sum, since 1995, the Commission's Communication established the fundamentals of the EU's long-term relationship with China, covering political dialogue, including specifically human rights; economics and trade; and the EU-China Cooperation Programme. To these three items, a fourth has recently been added relating to sectoral dialogues and agreements in more than 20 various fields, encompassing the protection of the environment, science and technology, industrial policy, education, culture and the like. The way China sees its role in the relationship is as depicted in 2003 in the China's EU Policy Paper which largely highlights the trade and investment aspects, but down plays, if not altogether categorically discarding, those relating to the socio-political arena. China's insistence on its 'domestic' socio-political stance is too obvious to warrant discussion, but its delay in the economic response needs explanation and the following section tries to do so.

\section{Explaining China's late reciprocation}

As argued above, the trade and investment considerations have been the driving force behind the EU initiation of the relationship. It is therefore pertinent to have the relevant data on them not only for their own sake but also to see if they help explain the late reciprocation by China and its relative coolness to the relationship.

Seen from the EU's own perspective, Table 1 and Fig. 1 show the evolution of EU commodity trade with China for two distinct periods: 1985-1994, with values in ECUs, the period immediately preceding the initiation of policy; and 1998-2002, in $€ \mathrm{~s}$, the period of the follow up of the relationship. The data is shown in one chart not just for mere convenience but also because there is no problem with the use of different units of value since the $€$ simply replaced the ECU at par.

The picture is strikingly clear. After running trade surpluses with China during 1985-1987, the EC went into deficits which, apart from a slight decrease in 1993, increased consistently during 1988-1994. What is crucial here is that the deficit was not due to declining exports since they were increasing fast during 1991-1993, after declining during 1986-1990; it was due mainly to the faster growth in imports. In other words, not only was the EC benefiting from China's economic growth, through increasing $\mathrm{FDI}^{29}$ and national income there stimulating higher imports from the $\mathrm{EC}$, but so too were EC consumers through cheaper imports from China. On the other hand, cheaper imports from China were a manifestation of the reality that EC producers were suffering from lack of competitiveness vis-à-vis Chinese exports, if not from worldwide exports. The combination of looming larger trade deficits with and deteriorating competitiveness relative to the fast-growing China, at a time when

\footnotetext{
${ }^{28}$ Commission of the European Communities (2006d).

${ }^{29}$ See El-Agraa and Wei (2006b) for the major role played by FDI in increasing Chinese imports.

型 Springer
} 
Table 1 EU commodity trade with China (ECU/€ billion)

\begin{tabular}{lrrr}
\hline Year & Exports & Imports & Balance \\
\hline 1985 & 7.181 & 3.936 & 3.245 \\
1986 & 6.533 & 3.223 & 2.316 \\
1987 & 5.533 & 5.239 & 2.946 \\
1988 & 5.801 & 7.539 & $\Delta 1.204$ \\
1989 & 6.372 & 9.148 & $\Delta 2.276$ \\
1990 & 5.271 & 10.587 & $\Delta 5.316$ \\
1991 & 5.605 & 14.972 & $\Delta 9.367$ \\
1992 & 6.852 & 16.783 & $\Delta 9.931$ \\
1993 & 11.302 & 19.538 & $\Delta 8.236$ \\
1994 & 12.447 & 22.706 & $\Delta 10.259$ \\
1998 & 17.411 & 41.974 & $\Delta 24.563$ \\
1999 & 19.351 & 49.655 & $\Delta 30.304$ \\
2000 & 25.498 & 70.275 & $\Delta 44.777$ \\
2001 & 30.087 & 75.915 & $\Delta 45.828$ \\
2002 & 33.981 & 81.289 & $\Delta 47.308$ \\
\hline
\end{tabular}

$\Delta$ means minus

Source: collected from Commission of the European Communities (1995, 2006e).

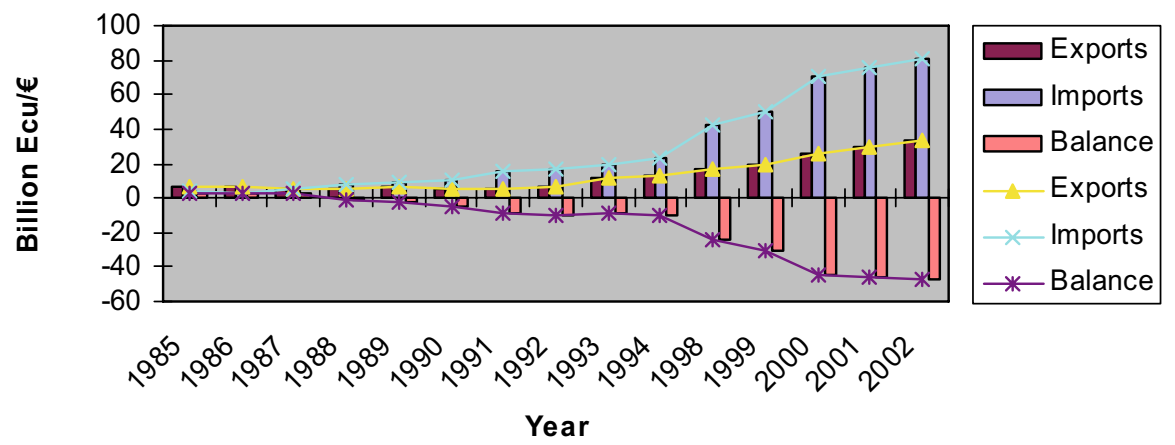

Fig. 1 EU commodity trade with China (Ecu/€)

competitiveness was uppermost in the EC agenda, must therefore have been instrumental in prompting the EC to pursue the relationship with China. It could of course be argued that the concern with EC competitiveness was not endorsed until 1999 and not formally adopted until $2000^{30}$ in Lisbon as the commitment to galvanize the EC in the following decade into 'the most competitive and dynamic knowledgebased economy in the world, capable of sustainable economic growth with more and better jobs and greater social cohesion.' In other words, the relationship policy preceded them by 4 years. Such an argument would however display complete ignorance of the average time taken by the EC to evolve a 'common position' on a new policy initiative, let alone formally adopt it; indeed competitiveness was what my 1997 paper $^{31}$ was all about and journals have very long gestation publications periods.

\footnotetext{
${ }^{30}$ European Council (2000).

${ }^{31}$ El-Agraa (1997) No. 444.
} 
Table 2 FDI flows to China, 1979-1993

\begin{tabular}{lrcc}
\hline & Project & Contracted capital (\$ million) & Used capital (\$ million) \\
\hline EU(12) & 2,741 & 6,952 & 2,442 \\
EU(15) & 3,070 & 7,319 & 2,549 \\
US & 12,019 & 14,659 & 5,237 \\
Japan & 7,182 & 8,935 & 5,203 \\
\hline
\end{tabular}

Source: Commission of the European Communities (1995) 279 final

Table 3 China's exports by continent and major area, 1981-2003

\begin{tabular}{|c|c|c|c|c|c|c|c|c|c|c|c|c|}
\hline \multirow[t]{2}{*}{ Year } & \multicolumn{2}{|l|}{ Asia } & \multicolumn{2}{|l|}{ Europe } & \multicolumn{2}{|c|}{ North America } & \multicolumn{2}{|c|}{ Latin America } & \multicolumn{2}{|c|}{ Australasia } & \multicolumn{2}{|l|}{ Africa } \\
\hline & $\$$ billion & $\%$ & $\$$ billion & $\%$ & $\$$ billion & $\%$ & $\$$ billion & $\%$ & $\$$ billion & $\%$ & $\$$ billion & $\%$ \\
\hline 1981 & 14.4 & 66.6 & 3.6 & 16.7 & 1.7 & 7.9 & 0.6 & 2.9 & 0.3 & 1.3 & 1.0 & 4.6 \\
\hline 1982 & 14.6 & 66.9 & 3.2 & 14.7 & 1.9 & 8.8 & 0.6 & 3.0 & 0.3 & 1.2 & 1.2 & 5.4 \\
\hline 1983 & 15.0 & 67.6 & 3.7 & 16.7 & 1.9 & 8.7 & 0.5 & 2.4 & 0.2 & 1.0 & 0.8 & 3.5 \\
\hline 1984 & 17.8 & 68.2 & 3.9 & 15.1 & 2.7 & 10.3 & 0.6 & 2.2 & 0.3 & 1.1 & 0.8 & 3.1 \\
\hline 1985 & 18.8 & 68.9 & 4.5 & 16.5 & 2.6 & 9.4 & 0.6 & 2.3 & 0.2 & 0.9 & 0.6 & 2.0 \\
\hline 1986 & 19.6 & 63.4 & 6.9 & 22.4 & 2.9 & 9.5 & 0.5 & 1.5 & 0.3 & 0.8 & 0.8 & 2.4 \\
\hline 1987 & 26.4 & 67.0 & 7.3 & 18.4 & 3.4 & 8.7 & 0.5 & 1.2 & 0.4 & 0.9 & 1.4 & 3.7 \\
\hline 1988 & 32.6 & 68.6 & 8.4 & 17.6 & 3.8 & 7.9 & 0.4 & 0.8 & 0.4 & 0.9 & 1.9 & 4.0 \\
\hline 1989 & 37.2 & 70.8 & 8.8 & 16.7 & 4.8 & 9.2 & 0.6 & 1.0 & 0.5 & 0.9 & 0.7 & 1.4 \\
\hline 1990 & 44.6 & 71.8 & 9.3 & 15.0 & 5.6 & 9.0 & 0.8 & 1.3 & 0.5 & 0.9 & 1.3 & 2.1 \\
\hline 1991 & 53.3 & 74.2 & 9.4 & 13.1 & 6.7 & 9.3 & 0.8 & 1.1 & 0.6 & 0.9 & 1.0 & 1.4 \\
\hline 1992 & 61.1 & 71.9 & 11.4 & 13.4 & 9.2 & 10.9 & 1.1 & 1.3 & 0.8 & 0.9 & 1.3 & 1.5 \\
\hline 1993 & 52.6 & 57.4 & 16.4 & 17.9 & 18.2 & 19.8 & 1.8 & 1.9 & 1.2 & 1.3 & 1.5 & 1.7 \\
\hline 1994 & 73.4 & 60.7 & 18.8 & 15.5 & 22.9 & 18.9 & 2.5 & 2.0 & 1.7 & 1.4 & 1.7 & 1.4 \\
\hline 1995 & 92.0 & 61.8 & 23.0 & 15.5 & 26.2 & 17.6 & 3.1 & 2.1 & 1.9 & 1.3 & 2.5 & 1.7 \\
\hline 1996 & 91.2 & 60.4 & 23.9 & 15.8 & 28.3 & 18.7 & 3.1 & 2.1 & 2.0 & 1.3 & 2.6 & 1.7 \\
\hline 1997 & 109.0 & 59.6 & 29.0 & 15.9 & 34.6 & 18.9 & 4.6 & 2.5 & 2.4 & 1.3 & 3.2 & 1.8 \\
\hline 1998 & 98.2 & 53.5 & 33.4 & 18.2 & 40.1 & 21.8 & 5.3 & 2.9 & 2.7 & 1.5 & 4.1 & 2.2 \\
\hline 1999 & 102.6 & 52.6 & 35.5 & 18.2 & 44.4 & 22.8 & 5.3 & 2.7 & 3.1 & 1.6 & 4.1 & 2.1 \\
\hline 2000 & 132.3 & 53.1 & 45.5 & 18.3 & 55.3 & 22.2 & 7.2 & 2.9 & 3.9 & 1.6 & 5.0 & 2.0 \\
\hline 2001 & 141.0 & 53.0 & 49.2 & 18.5 & 57.6 & 21.7 & 8.2 & 3.1 & 4.1 & 1.5 & 6.0 & 2.3 \\
\hline 2002 & 170.4 & 52.3 & 59.2 & 18.2 & 74.3 & 22.8 & 9.5 & 2.9 & 5.3 & 1.6 & 7.0 & 2.1 \\
\hline 2003 & 222.6 & 50.8 & 88.3 & 20.1 & 98.1 & 22.4 & 11.9 & 2.7 & 7.3 & 1.7 & 10.2 & 2.3 \\
\hline
\end{tabular}

Source: El-Agraa and Wei (2006a), p. 39

This disturbing realisation was reinforced by the extent of the flow of EC foreign direct investment (FDI) going to China. As the data in Table 2 for 1979-1993 clearly shows, the EC lagged behind both the US and Japan in all respects, i.e. the EC was suffering from its enterprises not gaining a proportionate share in the fast growing Chinese economy.

Turning to the Chinese perspective, Tables 3 and 4 provide the global distribution of China's exports and imports during 1980-2003. They show that just over half of the exports and almost two-thirds of China's imports were conducted with Asia, with Europe not only lagging far behind (20.1 and 16.9\%, respectively), but also less important than North America in terms of exports but slightly more important in terms of imports. Naturally, the picture was even more depressing for the EU relative to the whole of Europe as Figs. 2 and 3 reveal. ${ }^{32}$ Since the centre of gravity for

\footnotetext{
${ }^{32}$ The tables for these figures can be found in El-Agraa and Wei (2006a) or obtained from the author. 
Table 4 China's imports by continent and major area, 1981-2003

\begin{tabular}{|c|c|c|c|c|c|c|c|c|c|c|c|c|}
\hline \multirow[t]{2}{*}{ Year } & \multicolumn{2}{|l|}{ Asia } & \multicolumn{2}{|l|}{ Europe } & \multicolumn{2}{|c|}{ North America } & \multicolumn{2}{|c|}{ Latin America } & \multicolumn{2}{|c|}{ Australasia } & \multicolumn{2}{|l|}{ Africa } \\
\hline & $\$$ billion & $\%$ & $\$$ billion & $\%$ & $\$$ billion & $\%$ & $\$$ billion & $\%$ & $\$$ billion & $\%$ & $\$$ billion & $\%$ \\
\hline 1981 & 8.9 & 41.3 & 4.2 & 19.4 & 5.8 & 27.0 & 0.9 & 4.2 & 0.9 & 4.2 & 0.4 & 1.6 \\
\hline 1982 & 7.0 & 36.8 & 3.8 & 20.1 & 5.5 & 29.3 & 0.9 & 4.6 & 1.1 & 5.7 & 0.4 & 1.9 \\
\hline 1983 & 8.7 & 40.7 & 5.4 & 25.1 & 4.4 & 20.4 & 1.5 & 7.0 & 0.8 & 3.8 & 0.4 & 1.9 \\
\hline 1984 & 13.4 & 48.8 & 6.0 & 21.9 & 5.2 & 18.8 & 1.1 & 3.9 & 1.1 & 4.1 & 0.4 & 1.5 \\
\hline 1985 & 22.6 & 53.4 & 9.8 & 23.1 & 6.2 & 14.8 & 1.0 & 2.5 & 1.3 & 3.1 & 0.3 & 0.8 \\
\hline 1986 & 21.0 & 49.0 & 12.5 & 29.2 & 5.7 & 13.3 & 1.6 & 3.8 & 1.7 & 3.8 & 0.3 & 0.6 \\
\hline 1987 & 21.6 & 49.9 & 11.8 & 27.3 & 6.2 & 14.4 & 1.2 & 2.9 & 1.6 & 3.7 & 0.2 & 0.4 \\
\hline 1988 & 27.7 & 50.0 & 13.5 & 24.4 & 8.5 & 15.4 & 2.2 & 4.0 & 1.5 & 2.8 & 0.3 & 0.5 \\
\hline 1989 & 30.7 & 51.9 & 14.7 & 24.9 & 8.9 & 15.1 & 2.4 & 4.1 & 1.8 & 3.0 & 0.4 & 0.7 \\
\hline 1990 & 29.0 & 54.4 & 12.8 & 24.1 & 8.1 & 15.1 & 1.5 & 2.8 & 1.5 & 2.8 & 0.4 & 0.7 \\
\hline 1991 & 37.6 & 58.9 & 12.7 & 19.9 & 9.7 & 15.1 & 1.6 & 2.5 & 1.7 & 2.7 & 0.4 & 0.7 \\
\hline 1992 & 49.0 & 60.8 & 16.1 & 20.0 & 10.8 & 13.4 & 1.9 & 2.4 & 2.1 & 2.6 & 0.5 & 0.6 \\
\hline 1993 & 62.6 & 60.2 & 24.0 & 23.1 & 12.1 & 11.6 & 1.9 & 1.9 & 2.4 & 2.3 & 1.0 & 1.0 \\
\hline 1994 & 68.8 & 59.5 & 25.0 & 21.6 & 15.7 & 13.6 & 2.2 & 1.9 & 2.9 & 2.5 & 0.9 & 0.8 \\
\hline 1995 & 78.1 & 59.1 & 27.8 & 21.1 & 18.8 & 14.2 & 3.0 & 2.2 & 3.0 & 2.3 & 1.4 & 1.1 \\
\hline 1996 & 83.4 & 60.1 & 27.7 & 19.9 & 18.7 & 13.5 & 3.6 & 2.6 & 3.9 & 2.8 & 1.5 & 1.1 \\
\hline 1997 & 88.4 & 62.1 & 25.8 & 18.1 & 18.3 & 12.9 & 3.8 & 2.6 & 3.7 & 2.6 & 2.5 & 1.7 \\
\hline 1998 & 87.2 & 62.2 & 26.3 & 18.8 & 19.1 & 13.6 & 3.0 & 2.1 & 3.1 & 2.2 & 1.5 & 1.1 \\
\hline 1999 & 101.7 & 61.4 & 32.7 & 19.7 & 21.8 & 13.2 & 3.0 & 1.8 & 4.2 & 2.5 & 2.4 & 1.4 \\
\hline 2000 & 141.3 & 62.8 & 40.8 & 18.1 & 26.1 & 11.6 & 5.4 & 2.4 & 5.9 & 2.6 & 5.6 & 2.5 \\
\hline 2001 & 147.2 & 60.4 & 48.4 & 19.9 & 30.2 & 12.4 & 6.7 & 2.8 & 6.3 & 2.6 & 4.8 & 2.0 \\
\hline 2002 & 190.3 & 64.5 & 53.4 & 18.1 & 30.9 & 10.5 & 8.3 & 2.8 & 6.8 & 2.3 & 5.4 & 1.8 \\
\hline 2003 & 272.9 & 66.1 & 69.7 & 16.9 & 38.3 & 9.3 & 14.9 & 3.6 & 8.6 & 2.1 & 8.4 & 2.0 \\
\hline
\end{tabular}

Source: El-Agraa and Wei (2006a), p. 41

China's trade was Asia, it was therefore natural for China to be more concerned with that Continent and that goes a long way towards explaining China's cool response to the China-CU relationship. This is reinforced by the investment side of the relationship. As can be gathered from Table 5, the FDI coming to China from the EU, represented by Germany and the UK combined, was minuscule, amounting to $4.04 \%$ of actually utilised FDI (3.88\% of contracted FDI). This compared with $68.53 \%(67.32 \%)$ from the five Asian nations, of which Japan contributed $7.28 \%$ $(7.43 \%)$, and $8.79 \%(9.17 \%)$ from the US.

Figures 2 and 3 also show that during 1998-2002, the period before the China EU Policy Paper was issued, the EU's share of China's imports and exports were, on the whole, not changing much; China's exports actually increased in 2002, but that reinforces lack of concern on the part of China. ${ }^{33}$ There was therefore no reason for China to have been having concerns about trade relations with the EU. When this is combined with the miserable FDI coming to China from the EU, this conclusion is reinforced. Given no worries and that Asia was the centre of trade and investment gravity for China, one cannot escape the conclusion that it was the bargaining inherent

\footnotetext{
${ }^{33}$ It could of course be argued that China should have been concerned about its increased exports to the EU since they could have invited trade restricting reactions on the part of the EU: witness the actions taken against Chinese textiles (the bras war) and not settled until September 2005, and shoes. However, that would have hardy been the basis for entering into a 'relationship' along the lines developed here, since it would have been tantamount to asking for a 'dispute-settling mechanism,' the appropriate place for which is the WTO which China joined in 2001.
} 
Table 5 The inflows of FDI into China by origin country or region, 1979-2003

\begin{tabular}{lrrrrrr}
\hline Country/region & Number of projects & Percent & $\begin{array}{l}\text { Contracted FDI } \\
\text { (\$billion) }\end{array}$ & Percent & $\begin{array}{l}\text { Actually utilized } \\
\text { FDI (\$ billion) }\end{array}$ & Percent \\
\hline Hong Kong & 224,509 & 48.25 & 414.51 & 43.95 & 222.58 & 44.38 \\
United States & 41,340 & 8.89 & 86.44 & 9.17 & 44.09 & 8.79 \\
Japan & 28,401 & 6.10 & 57.49 & 6.10 & 41.39 & 8.25 \\
Taiwan & 60,186 & 12.94 & 70.03 & 7.43 & 36.49 & 7.28 \\
Virgin Islands & 8,877 & 1.91 & 62.01 & 6.58 & 30.17 & 6.02 \\
Singapore & 11,871 & 2.55 & 43.57 & 4.62 & 23.53 & 4.69 \\
South Korea & 27,128 & 5.83 & 36.65 & 3.89 & 19.69 & 3.93 \\
United Kingdom & 3,856 & 0.83 & 20.84 & 2.21 & 11.44 & 2.28 \\
Germany & 3,504 & 0.75 & 15.71 & 1.67 & 8.85 & 1.76 \\
Others & 55,605 & 11.95 & 135.90 & 14.38 & 72.27 & 12.62 \\
Total & 465,277 & 100.00 & 943.15 & 100.00 & 501.50 & 100.00 \\
\hline
\end{tabular}

Source: El-Agraa and Wei (2006b), p. 10

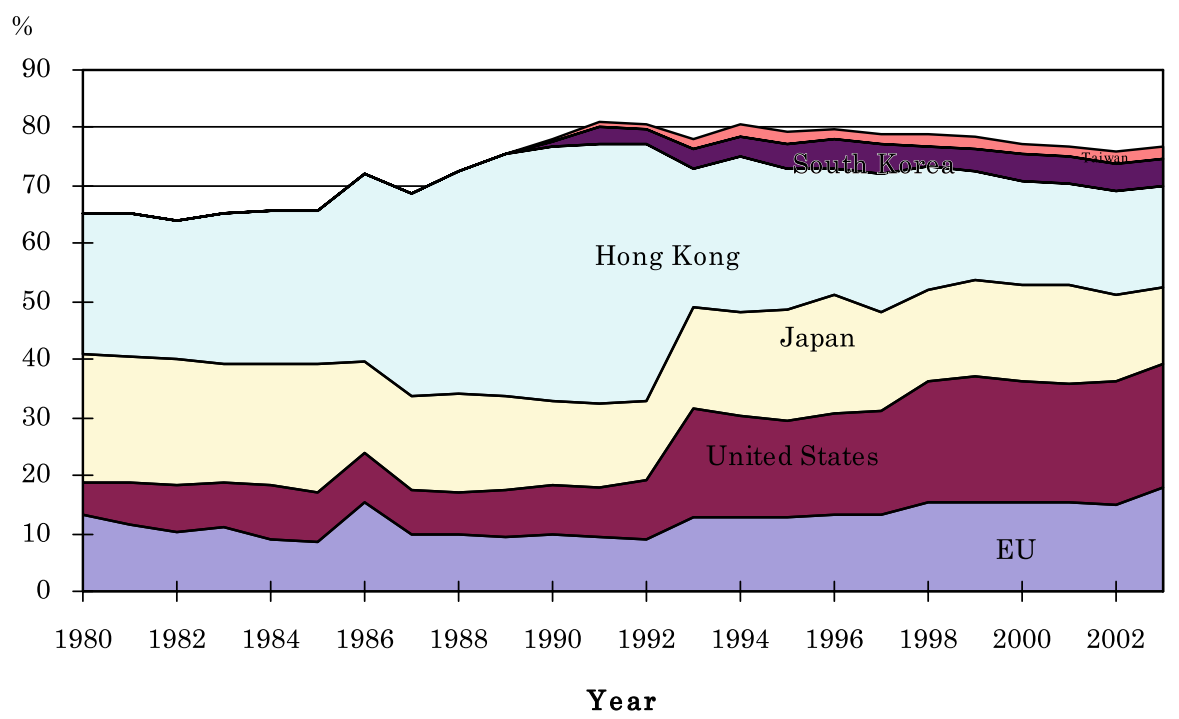

Fig. 2 China's exports to the main countries and regains, 1980-2003

in the WTO negotiations process that persuaded China to indulge in the relationship offered by the EU. Of course, one could counter by asking why the response came after China formally joined WTO in 2001. Again, however, the answer would be that the EU-China Bilateral Agreement, needed for WTO membership, was not concluded until 19 May 2000 (see above); hence for China to have offered its EU Policy paper before or soon after that date would have looked very odd by WTO membership negotiations standards which require extending equal treatment to all. There is also the already mentioned slow Chinese political decision process.

To complete the picture, one has to look into what China has been doing. In 2003, it, together with Japan, South Korea and the ten member nations of ASEAN agreed to create the ASEAN +3 'preferential trading agreement,' which is yet to be finalised, but the negotiations for it go back as far as the Asian financial crisis of 1997 if not before. In iㅡㄹ Springer 


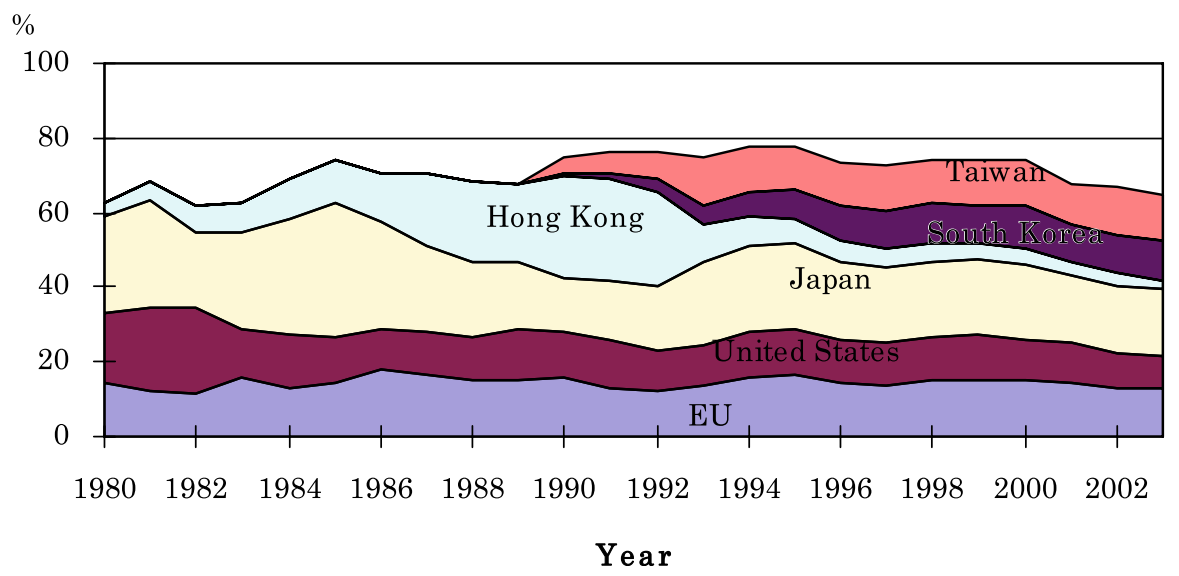

Fig. 3 China's imports from main countries and regions, 1980-2003

other words, China has been exerting its utmost in terms of 'cooperation' in Asia; hence its relative coolness to those outside the region, including the EU; rather EU nations since although the EU's 'common commercial policy' (CCP) is conducted by the Commission on behalf of all member nations, ${ }^{34}$ trade and investment are run nationally. Not only that, but it has been aggressively building a leadership role in East Asia, marginalising Japan: witness its efforts to establish a leadership role for the ASEAN+3 when Japan was the instigator and its relegation of Japan to the sidelines in the January 2007 Asian summit, held in the Philippines; its disapproval of a permanent seat for Japan in the UNSC; ${ }^{35}$ and the mentioned enticement of the DPRK back into the six-nation talks, in spite of the fact that, as stressed at the beginning, in doing so it is also protecting itself against an influx of escapees from the DPRK and enhancing its own security by promoting a nuclear-free Korean zone. ${ }^{36}$ Furthermore, and again as already stated, in holding/hosting the FOCAC summit in November 2006 with all the African nations bar two and following it by the visit by Chinese

\footnotetext{
$\overline{34}$ See El-Agraa (2004a, chapter 2) and Brülhart and Matthews (2004).

35 'China's new clout within Asia was demonstrated last year, when Japan discovered that only tiny Singapore, was willing to come out in strong support of Japan's bid for permanent membership of the United Nations Security Council,' wrote Rachman (2007).

${ }^{36}$ Indeed, in the early morning of 13 February 2007, the six-nation group finally managed to reach agreement. In the 'deal, which cemented China's emergence as a significant power-broker on the world stage, North Korea agreed to close down its main nuclear reactor within 2 months and allow international inspectors to verify the process,' the Financial Times, 'Washington moves towards normal relations; Pyongyang to close reactor under supervision; Japan voices doubts about deal,' by Fifield and Dombey (2007). The DPRK's enticement into the deal was made possible not only because it was promised 50,000 tons of heavy fuel oil, food and other aid and another 950,000 tons of fuel oil when it provided a complete list of its nuclear programmes and disabled all existing facilities. It was also because the US agreed to commit to bilateral talks with the DPRK which would eventually lead to full diplomatic relations and would resolve within 30 days the dispute over \$24 million in DPRK-linked accounts frozen 18 months earlier as part of a US-led crackdown on counterfeiting and money laundering. This important development is not quoted in the main text because the DPRK has a history of reneging on agreements, especially if what it was offered in order to secure the deal did not arrive and to its satisfaction. Nevertheless, it is historic in terms of China's success as a global mediator especially when the deal led to the US more or less reversing its policy stance towards the DPRK.
} 
President $\mathrm{Hu}$ Jinato to eight African nations in January/February 2007, his third in 2 years, it has demonstrated that it is seeking global leadership, again, even though some would counter by reiterating self-interest since much needed energy and mineral resources come to it from Africa, but that hardly negates my assertion and many would argue that the US has been doing likewise for decades and so did Britain when it ruled the waves. What is even more revealing is that although China's President Hu Jintao visited Poland in June 2004 and Germany, the UK and Spain in November 2005, he has still to visit the EU. Revealing because, as already stated the Commission has the sole responsibility for the EU's CCP, i.e. trade matters are not in the hands of individual EU nations; hence in not paying an official visit to the Commission while he is in Europe, he is suggesting that China values bilateral relations more than the China-EU Relationship. This may appear to be fine since the EU is still to have a true 'common foreign policy,' but as indicated, the EU has a CCP, so when the President of China excludes the Commission from his European itinerary, his country is clearly behaving in a manner which suggests that it is more concerned with foreign policy matters than with the established EU-China Relationship. Indeed, this conduct is consistent with the mentioned insistence by China in its EU-China Policy Paper on the EU keeping off all matters not related to trade and investment: by its President visiting the Commission, China would seem to be endorsing the 'full package' of the EU-China Policy Paper. ${ }^{37}$ And so on and so forth.

To put it in a nutshell, China sees itself not only as the major player in Asian affairs, but as the next hegemon; hence its reluctance to be perceived as being concerned with simply a bilateral relationship with the EU, especially when trade and investment are conducted on a national, not an EU, basis. This conclusion is reinforced when one realises the absence of a declared relationship with the US, the number one destination of its exports (see Fig. 2) and FDI outflows and to whose currency it pegs the renminbi (or yuan). Although the latest data, show that the EU has become China's largest trader, this does not change the basic picture: although in 2003 China's imports from the EU exceeded those from the US (respectively, 13.2 versus $8.2 \%$ of total Chinese trade; see Fig. 3), the opposite was true for imports (17.9 and 21.1\%; see Fig. 3). I have not used the 2004 data because it is not available in the consistent manner utilised here, but assuming that the 2004 data provided by the EU is correct and that the change from 2003 must, in the absence of miracles, be small, the EU must be referring to total trade, but the sum of these percentages clearly points to a minuscule difference. Moreover, one could argue that China's primary concern is the APEC forum; adding the US to the Asian picture depicted in this paper. After all, some would argue that as a regional trade and investment bloc, the APEC forum is an analogous 'declared relationship' between the member nations. Such an argument would not wash, however, given the organisation's commitment to 'open regionalism,' i.e. privileges are self-declared

\footnotetext{
${ }^{37}$ One could of course counter by claiming that China may not be aware of the fact that the Commission has the sole responsibility for the CCP, in which case we would be going back decades, evoking a sense of déjà vu, to when Japan had to be subjected by France to the 'Poitiers incident' before it got the message that it had to deal with the Commission, not France, in the face of French intransigence of world trade rules, but one should be very surprised to learn that China is that ignorant of how the EU operates; on this, see, inter alia, Hosoya (1979), Anouil (1985), and El-Agraa (1988, 1998).
} 
and extended to all nations irrespective of membership; otherwise why the recent drive by the US to establish preferential trading agreements with some of APECs's member nations. ${ }^{38}$ Moreover, and vitally, to argue so would be in direct contradiction to China's ultimate goal of becoming the global leader. In other words, although all indications, including the existence of a large Chinese community in the US, suggest that China should be preoccupied with prioritising the development of a China-US relationship, seeking to become the next hegemon deters China from doing so, especially when the APEC forum, albeit superficially does so. This reinforces the argument in favour of appeasing the EU; one needs friends in order to assume world leadership, so what is better than a group of nations acting in unison as the EU when in reality they conduct their trade and investment individually! Finally, one should mention China's military build-up ${ }^{39}$ and increasing sophistication ${ }^{40}$ which reinforce its determination to become the next hegemon.

\section{Conclusion}

The conclusion is simple and straightforward. China perceives its relationship with the EU within its overall future prospects which its population size, current economic surge and military build-up and enhanced sophistication suggest are enormous. Serious analysts have concluded that the Chinese do not see themselves as a rising new power, but as Asia's traditional power, now experiencing a renaissance: 'China, they believe, is regaining the status and prestige that it enjoyed until the end of the 18th century. ${ }^{41}$ Here, I go beyond that to argue that China sees its importance not in Asian, but in global terms, but becoming the Asian hegemon will pave the way to that higher goal. China therefore sees its relationship with the EU within how it fits into this general picture.

\footnotetext{
${ }^{38}$ At the Osaka, Japan, APEC summit meeting in November 1995, China's President Jiang Zemin announced unilateral tariff cuts of $30 \%$ in more than 4,000 items, effective from April 1996, to demonstrate APEC's commitment to 'open regionalism,' i.e. member nations extended their privileges also to non-members. That was a brilliant ploy because China had to make these cuts in order to stand a chance to become a WTO member! For a detailed discussion within a comprehensive coverage of China's tariff policies, see, inter alia, the Hoover Institution (2007).

${ }^{39}$ A recent study by the RAND Corporation (2007) estimates China's defence spending to be between 2.3 and $2.8 \%$ of its GDP, which is $40-70 \%$ higher than the official figure. It also points out that China doubled this expenditure between 1997 and 2003 to nearly reach that of the UK and Japan, and it continued to grow at an annual rate of $10 \%$ during 2003-2005. Although that still leaves China with expenditure equal to one-fifth that of the US, growth at these rates means that China will become a formidable military nation within the next few decades. Detailed information can also be found at: http://en.wikipedia.org/wiki/China's_military_spedendin and in Global Security Organization for various years at http://www.globalsecurity.org/military/world/china/ budget.htm. Although a study by the SIPRI (Stockholm International Peace Research Institute) (2005) produces lower figures, indicating that China surpassed only Japan in relative terms and Russia in absolute terms, it corroborates the RAND conclusion that China's military expenditure is higher than is depicted by the official budgetary figures; for the general website see http://www.sipri.org/contents/milap/milex/ mex_database1.html and for the specific study in consideration, see http://first.sipri.org/non_first/result_ milex.php.

${ }^{40}$ On 11 January 2007, China successfully used a ground-based, medium-range ballistic missile to destroy its own old weather satellite from its orbit about 537 miles above Earth.
}

${ }^{41}$ See, inter alia, Moisi (2007). 
It is interesting to note that a day after this paper was finalised, Gideon Rachman ${ }^{42}$ of the Financial Times wrote: 'The past decade has seen at least three major developments that demonstrate China's burgeoning global power. The first is the way that China is displacing Japan as the diplomatic and economic focus of Asia. The second is the growing power of the Chinese military. The third is the fact that China is now developing global strategic interests.' Although Rachman offered alternative interpretations of these for global power in the future, in the light of what has been discussed in this paper, the picture should be much clearer regarding where China is heading to; hence on its position concerning its relation with the EU.

Acknowledgement I wish to express my gratitude for comments and helpful suggestions from Professor Philip Arestis, Director of Research, Cambridge Centre for Economic and Public Policy, the University of Cambridge, UK, Professor Marius Brülhart of HEC, Université de Lausanne, Switzerland, Emeritus Professor Dermot McAleese, Trinity College, Dublin, Ireland, Jean Monnet Professor Alan Matthews of Trinity College, Dublin, Ireland, Brian Ardy, Head of the European Institute, London South Bank University, UK, and Dr Albrecht Rothacher, Editor-in-Chief of this Journal. I am especially indebted to Professor Matthews for provoking me into pursuing directions that I had not envisaged. Nevertheless, I must absolve all of them of any responsibility for any of my errors.

\section{References}

Algieri C (2002) EU economic relations with China: an institutional perspective. Chin Q (Lond) 169 (March)

Anouil G (1985) EU-Japan relations at a turning point. EC Studies in Japan 18(5)

Bhagwati J (2002) Free trade. Princeton University Press, Princeton, NJ

Brülhart M, Matthews A (2004) External trade policy. In: El-Agraa AM (ed) The European Union: economics and policies. The 8th edition of which will be issued by Cambridge University Press in early 2007

China View (2007) Chinese President Hu Jintao wraps up successful African trip. http://news.xinhuanet. com/english/2007-02/11/content_5724926.htm

Commission of the European Communities (1985) Agreement on trade and economic cooperation between the European economic community and the People's Republic of China-1985. http://ec. europa.eu/comm/external_relations/china/intro/1985_trade_agreement.htm

Commission of the European Communities (1994) Endorsement by the council, held on 9/10 December 1994, of the commission's 'Towards a new Asia strategy,' COM(94) 314. Bull Eur Union 7/8:82 (12:14-15)

Commission of the European Communities (1995) A long term policy for China-Europe relations. Communication of the Commission, COM(1995) 279 final. Brussels

Commission of the European Communities (1998) Building a comprehensive partnership with China. Communication from the Commission, COM(1998) 181. Brussels

Commission of the European Communities (2000) On the implementation of the Communication "building a comprehensive partnership with China." Report from the Commission to the Council and the European Parliament, COM(2000) 552. Brussels

Commission of the European Communities (2001) EU strategy towards China: implementation of the 1998 communication and future steps for a more effective EU policy. Communication from the Commission to the Council and European Parliament, COM(2001) 265 final. Brussels

Commission of the European Communities (2006a) A maturing partnership-shared interests and challenges in EU-China relations. Communication from the Commission to the Council and European Parliament, COM(2003) 533 final. Brussels

\footnotetext{
$\overline{42}$ Gideon Rachman, 'As America looks the other way, China's rise accelerates' in the Financial Times, 13 February 2007. Also see Jim Yardley and David E Sanger, 'Nuclear accord set with North Korea: $\$ 400$ million in fuel oil and other aid, but no agreement on disabling weapons,' International Herald Tribune, 14 January 2007.
} 
Commission of the European Communities (2006b) EU-China: closer partners, growing responsibilities. Communication from the Commission to the Council and European Parliament COM(2006) 831 final. Brussels

Commission of the European Communities (2006c) Closer partners, growing responsibilities — a policy paper on EU-China trade and investment: competition and partnership COM(2006) 631 final. Brussels

Commission of the European Communities (2006d) Commission working document, accompanying COM (2006) 631 final: closer partners, growing responsibilities - a policy paper on EU-China trade and investment: competition and partnership. Brussels

Commission of the European Communities (2006e) The EU's relations with China. http://ec.europa.eu/ comm/external relations/china/intro/

Eglin M (1997) China's entry into the WTO with a little help from the EU. International Affairs 73(3): 489-508 (July)

El-Agraa AM (1988) Japan's trade frictions: realities of misconception? Macmillan, London

El-Agraa AM (1997) UK competitiveness versus Japanese industrial policy. Econ J 107:1504-1517

El-Agraa AM (1998) The European community's internal market and Japan's response. EC Studies in Japan 21(5)

El-Agraa AM (1999) Regional integration: experience, theory and measurement. Macmillan, London

El-Agraa AM (2001) Dialogue amongst regional cooperative societies for the promotion of inter-regional cooperation towards global integration. In: Young Seek Choue (ed) Toward a global common society through dialogue among civilizations. Institute of International Peace Studies, Kyung Hee University, Seoul

El-Agraa AM (ed) (2004a) The European Union: economics and policies. Prentice Hall, Englewood Cliffs, NJ (the 8 th edition (2007) by Cambridge University Press)

El-Agraa AM (2004b) Is globalization causing increased poverty and income inequality? Journal of the BWW Society 1, July. http://www.bwwsociety.org/journal/html/poverty.htm

El-Agraa AM, Wei LP (2006a) The direction and composition of China's trade: an unexpected composition of exports for a developing nation? Journal of Far Eastern Business and Economy 3:32-56

El-Agraa AM, Wei LP (2006b) Rationalising the dramatic change in the composition of China's exports. Asia Pac Econ J 4:1-28

European Council (1999) Cologne European Council. Bull Eur Union 6

European Council (2000) Presidency conclusions: Lisbon European Council 23 and 24 March 2000. Bull Eur Union 3

Fifield A, Dombey D (2007) Washington moves towards normal relations; Pyongyang to close reactor under supervision; Japan voices doubts about deal. The Financial Times, 14 February

Financial Times (2006) 12 January

Fischer S (2003) Globalization and its challenges. Am Econ Rev 93:1-30

Global security organization (various years) China's defence budget. http://www.globalsecurity.org/ military/world/china/budget.htm

Griese G (2006) EU-China relations - an assessment by the communications of the European union. Asia Europe Journal 4(4):545-553 (December)

Hoover Institution (2007) An assessment of Chinese thinking on trade liberalization. http://www.hoover. org/publications/he/286666.html?show=essay

Hosoya C (1979) Relations between the European Communities and Japan. J Common Mark Stud 18(2)

Kapur H (1981) The awakening giant: China's ascension in world politics. Sijthoff \& Noordhoff, Alphen aan den Rijin

Ministry of Foreign Affairs of the People's Republic of China (2003) China's EU policy paper, October 13. http://www.fmprc.gov.cn/eng/wjb/zzjg/xos/dqzzywt/t27708.htm

Moisi D (2007) Europe's distant mirror. The Japan Times, 27 January

OECD (2007) Science, technology and industry outlook 2006. OECD, Paris. http://www.oecd.org/sti/outlook

Pan E (2007) China, Africa and oil. Can be accessed from the website of the Council on Foreign Relations: http://www.cfr.org/publication/9557

Rachman G (2007) As America looks the other way, China's rise accelerates. The Financial Times, 13 February

RAND Corporation (2007) China. http://www.rand.org/hot topics/china

SIPRI (2005) The SIPRI military expenditure database. http://www.sipri.org/contents/milap/milex/ $\mathrm{mx}$ _database1.html and specifically at http://first.sipri.org/non_first/result_milex.php

World Bank (1977) World development report 1977. Oxford University Press

Worldpress.org (2007) China to double aid to Africa. http://www.worldpress.org/print_article.cfm? article_id=2674\&dont=yes

Yardley J, Sanger DE (2007) Nuclear accord set with North Korea: \$400 million in fuel oil and other aid, but no agreement on disabling weapons. Int Her Trib, 14 January 